\title{
Bullying and Cyberbullying in Thailand: Coping Strategies and Relation to Age, Gender, Religion and Victim Status
}

\author{
Ruthaychonnee Sittichai ${ }^{*}$, Peter K. Smith² \\ 'Faculty of Humanities and Social Sciences, Prince of Songkla University, Thailand \{ruthaychonnee.s@psu.ac.th\} \\ 2Department of Psychology, Goldsmiths, University of London, United Kingdom \{p.smith@gold.ac.uk\}
}

Received on 05 June 2017; revised on 27 September 2017; accepted on 13 October 2017; published on 15 January 2018

\begin{abstract}
Both traditional (offline) and cyber (online) bullying amongst children and young people are serious problems internationally, including in Thailand. Most studies of these were conducted in western countries, with research in Asian countries much less common. We report on a survey of 1,049 students ( $42 \%$ boys, $58 \%$ girls) aged 12 to 18 years, in 12 schools from 3 provinces in southern Thailand, of experiences of being a victim of traditional and cyberbullying over the past couple of months, and recommended coping strategies. Telling a teacher or parent was the most recommended strategy for traditional victimization; this was less so for cyber victimization, where blocking messages/identities or changing email address or phone number were most recommended. Older pupils were more likely to recommend reporting to the police, and keeping a record of bullying incidents. There were many gender differences, with girls recommending telling and reporting more, for both traditional and cyber victimization. Girls also recommended ignoring it more, or blocking messages; while boys recommended fighting back, but also making new friends. There were few differences by religion. Victims were more likely to recommend passive strategies such as avoiding the victims, or risky ones such as fighting back. Findings are discussed in relation to previous research, and implications for anti-bullying work in schools.
\end{abstract}

KEYWORDS: BULLYING, CYBERBULLYING, VICTIMIZATION, COPING, THAILAND

\section{INTRODUCTION}

Bullying is usually defined as being aggressive, intentional behavior that is carried out by a group or an individual, repeatedly and over time, against a victim who cannot easily defend him or herself (Olweus, 1999); it is based on an imbalance of power and can also be defined as a systematic abuse of power (Smith, 2014; Rigby, 2002). Traditional or offline bullying takes several forms, but in the last decade especially, cyberbullying has emerged through the use of modern communication technologies (Kowalski et al., 2014; Tokunaga, 2010).

*To whom correspondence should be addressed:

Faculty of Humanities and Social Sciences, Research Center for Educational Innovations and Teaching and Learning Excellence, Prince of Songkla University, Pattani, 94000, Thailand
The main types of traditional bullying are physical bullying (kicking, hitting, punching, slapping, shoving and other physical attacks), verbal bullying (threatening statements, name-calling, insulting; direct relational (social exclusion); and indirect relational (rumour spreading). Cyberbullying is typically defined as aggression that intentionally and repeatedly carried out via mobile phones and the internet, against a person who are not be able easily defend him/herself (Kowalski, et al., 2014; Patchin \& Hinduja, 2012; Smith et al., 2008). Cyberbullying can be via phone calls, text messaging, instant messaging, e-mail, chat rooms or on social networking sites such as Facebook and Twitter.

\subsection{Coping strategies}

Victims of bullying may attempt to cope with it in various ways. Traditional coping strategies include problem solving approaches such as making new friends; seeking social support; confronting or retaliating such as fighting back; and more passive strategies such as ignoring or avoiding it.

Smith, Shu, and Madsen (2001) found that (for traditional victimization) the most common coping strategies used by $10-14$ year-old victims in England, were ignoring the bullies, followed by telling them to stop, asking an adult for help, and fighting back; the least used coping strategies were running away, asking friends for help, and crying. Younger children more often reported crying or running away, while older children more often reported ignoring the bullies. Girls more often reported crying or asking a friend or adults for help, and boys more often reported fighting back.

Kristensen and Smith (2003) investigated five coping strategies that Danish children aged 10-15 years said they would employ. In order of preference these were Self-Reliance/Problem-Solving, Distancing, Seeking Social Support, Internalizing, and Externalizing. Seeking Social Support and Internalising were more frequent in girls, Externalising more frequent with boys; and Distancing, Seeking Social Support, and Internalising were more frequent in younger children.

The most consistent gender difference in coping strategies appears to be in a greater willingness of girls to seek social support. The likelihood of telling a teacher is greater in girls, and 
also in younger pupils (Hunter \& Boyle, 2004; Naylor, Cowie, \& del Rey, 2001). This is true for cyber as well as traditional victims (Raskauskas \& Huynh, 2015). Girls and younger children are more likely to talk about unpleasant situations online. This interacts with age: while girls remain more communicative at all ages if they are bullied online, boys become less talkative as they get older. Girls and older teenagers also tend to use more proactive coping strategies in situations of online bullying, sexual images, and privacy misuse (Vandoninck \& Haenens, 2015).

Children and young people cope with cyberbullying in various ways (Raskauskas \& Huynh, 2015). They may use traditional strategies (Riebel, Jäger, \& Fischer, 2009), but many victims of cyberbullying use technology to solve the issue. In a sample from mainland China, Zhou et al. (2013) reported that $46 \%$ ignored/ did not react, $36 \%$ talked about the experience/sought help (of these, from classmates/friends $66 \%$, parents $29 \%$, siblings $28 \%$, teachers $3 \%$ ), $32 \%$ deleted the materials, $25 \%$ changed their online account, and $12 \%$ sought revenge.

Technical solutions can include avoidant coping behaviors such as changing the username or account ID, changing email address or phone number, unfriending on social media, and/or blocking messages or users (Aricak et al., 2008; Juvonen \& Gross, 2008; Smith et al., 2008). Juvonen and Gross (2008) reported that $67 \%$ of participants in a US sample had blocked someone, $33 \%$ had removed the person from their friends list on the website, and $26 \%$ had changed their username or email.

In a Swiss study, Machmutow et al. (2012) suggested a different set of coping strategies for cyberbullying, including distant advice, assertiveness, helplessness, close support, and retaliation, based on a factor analysis of coping items. They found that over time, support seeking from peers and family was associated with reduced depression, while assertive coping strategies (such as finding and contacting the bully) were associated with increased depression. Vollink et al. (2013) described avoidance coping, optimistic coping, coping through emotional expression, depressive coping, social support seeking, palliative coping through confrontation, in a Belgian sample. They found that victims of cyberbullying who used more depressive coping internalized their feelings and did not take action to change the situation.

There has been limited comparison of the strategies used by pupils in response to traditional bullying compared to cyberbullying. However Slonje and Smith (2008) found that Swedish pupils were more likely to seek support by telling someone, for traditional bullying, than they were for cyberbullying, being especially less likely to tell teachers about the latter.

A few studies have looked at how coping strategies vary, by victim status. Bijttebier and Vertommen (1998) reported that with 9-13-year-olds in Flanders, Belgium, male victims scored higher on internalising coping strategies, compared with not involved male peers. Findings for female victims were less clear, with internalising strategies being high in female victims of direct bullying but not in female victims of social isolation.

The above studies were all carried out in western countries. Kanetsuna and Smith (2002) compared coping strategies approved of by English and Japanese secondary school students. Telling someone (teacher, parents or friends) was most recommended by English students, but less so by Japanese students, who rather favored direct action such telling the bullies to stop, or fighting back.

\subsection{Studies on bullying and cyberbullying in Thailand}

There has been rather limited research on bullying and cyberbullying in South-East Asian countries, including Thailand. Sittichai and Smith (2015) reviewed studies up to 2014. There were several studies on prevalence of traditional bullying, and these generally found expected gender differences (boys more involved as bullies), and risk factors; there has been very little research on coping strategies. Two small-scale studies have been reported on coping with cyberbullying.

Sittichai and Tudkea (2015) reported qualitative research on cyberbullying behaviors, using semi-structured interviews with twenty seven victims and perpetrators. For coping with cyberbullying, some kept quiet, deleted or blocked others, responded or cyberbullied back, compromised, or stopped or cancelled access to social networking. They rarely dealt with cyberbullying by consulting their parents or relatives, but some consulted their close friends.

Promnork (2015) studied the coping strategies of pupils affected by cyberbullying, using a survey of internet usage among students of a Bangkok upper elementary school, and in-depth interviews with five victims of cyberbullying. When faced with problems, pupils tended to cope by using the simplest and quickest strategies, mainly avoidant strategies, which are often not the best. They did unfriend status on social networking; did not go to school or avoided meeting friends at school; deleted their profile pictures or text. This study found that once someone was told about the bullying, good relationships between family members and school personnel could help solve the problem.

The study here was carried out in the southern provinces of Thailand. These are somewhat distinct from the rest of Thailand in having a substantial Malay language population with Muslim religion, in contrast to the Buddhist religion which characterizes most Thai language speakers in the rest of the country. There have been considerable levels of violence in these provinces in recent decades. This sample therefore offered the chance to put in religion (as well as age and gender) as a demographic factor. Religion could be a factor, as Laeheem, Kuning and McNeil (2009) found that non-Muslim pupils in southern Thailand were more involved in traditional bullying perpetration, than Muslim pupils.

\section{OBJECTIVES}

The objectives were (1) to examine what pupils thought were the best coping strategies for traditional and for cyber victimization, (2) to compare (where possible) recommended coping strategies for dealing with traditional victimization compared to cyber victimization, and (3) to examine how four factors were associated with these: (i) age, (ii) gender, (iii) religion, and (iv) victim/ non-victim status.

\section{METHODS}

Research design: We used a cross-sectional survey, carried out in 2012. We assessed demographic information, ICT use, and experiences with bullying and cyberbullying, including recommended coping strategies. Data collection was done by the author with the help of experienced assistant researchers. 
Context: Data was collected from 12 secondary and high schools in Pattani, Yala, and Narathiwat provinces in southern Thailand. Four schools in each province were selected by random sampling and all schools agreed to participate.

Sample: Students aged 12 to 18 years (400 students from each province) were invited to participate. This initial sample of 1,200 fell to 1,183 who responded; this was the sample used in Sittichai (2014), who reported on prevalence data, and risk factors for being a victim. However after excluding participants with missing data in coping strategies, this fell to a final total of 1,049 adolescents used in this analysis.

Table 1 shows demographic characteristics of the sample by gender. The sample was approximately equally divided by age (12-15 years; $16-18$ years) and gender, although with a somewhat higher proportion of girls. About two-thirds of the students were Islamic, but nearly one-third were non-Islamic (almost all of these were Buddhist, but for purposes of analysis 7 'other' non-Islamic students were added to this category).

Instruments: The students were given a questionnaire concerning demographic information (age, gender, religion), ICT use (ownership of mobile phones and smart phones, access to and use of the internet), and experiences with bullying and cyberbullying, including recommended coping strategies. The questionnaire was based on one used previously in England (Smith et al., 2008). It was translated into Thai and checked by back translation.

To ascertain victim status, standard definitions of bullying and cyberbullying were given in the information sheet at the start of the questionnaire:

Bullying is an action carried out by a group or individual that is repeated over time in order to hurt, threaten or frighten an individual with the intention to cause distress. It is different from other aggressive behavior because it involves an imbalance of power which leaves the victim defenseless.

Cyberbullying is a new form of bullying which involves the use of e-mail, instant messaging, chat rooms, websites, mobile phones or other forms of information technology to deliberately harass, threaten, or intimidate someone. Cyberbullying can include such acts as making threats, sending personal, racial or ethnic insults or repeatedly victimizing someone through electronic devices.
Students were then asked 'Have you been bullied at school in the past couple of months?' for traditional bullying (not including cyberbullying), and 'Have you been cyberbullied at school in the past couple of months?', both on a standard 5-point scale (never, it has only happened once or twice, two or three times a month, about once a week, several times a week). Traditional and cyber victims were scored as all those who answered that they had been bullied.

After this (and other questions) they were asked "What do you think are the best ways to stop 'traditional' bullying?', with 10 categories (see Table 2); and 'What do you think are the best ways to stop cyberbullying?', with 8 categories (see Table 3 ). Students could tick all categories that they thought applied, for these two questions. They also had the option of checking 'Other (please state)' at the end.

\section{ANALYSES}

We first report descriptive statistics on ICT use and victim status. Then, chi-square tests were performed for choice of coping strategies, by traditional and cyberbullying victim status. Finally, multiple linear regression was used to compare coping strategy choice by four binary factors: age, gender, religion and victim/ non-victim status. Data management and analysis were performed by SPSS Version 17.

\section{RESULTS}

\subsection{ICT use}

Most adolescents (87\%) had their own private mobile phones and nearly half of them had a smart phone. Girls had comparatively higher smart phone ownership than boys. Almost all adolescents (98\%) used the Internet, and over half accessed it at home.

\subsection{Victim status}

Table 1 shows numbers of victims, and cyber victims. Altogether $15.9 \%$ were traditional victims and $15.1 \%$ were cyber victims. Boys were more often victims than girls for both traditional and cyber forms, but this was only significant for cyber victimization.

Table 1. Comparison of demographic characteristics between boys and girls

\begin{tabular}{|c|c|c|c|c|c|}
\hline & & \\
\hline & & Boys & $\begin{array}{c}\text { Chicas } \\
(\mathrm{n}=\mathbf{6 0 5}, \mathbf{5 7 . 7 \%})\end{array}$ & $\underset{(n=1049)}{\text { Girls }}$ & P-value \\
\hline \multirow{2}{*}{ Age } & $12-15$ years & $(\mathrm{n}=444,42.3 \%)$ & Girls & $588(55.9)$ & \multirow{2}{*}{0.732} \\
\hline & $16-18$ years & $(\mathrm{n}=605,57.7 \%)$ & Total & $454(43.6)$ & \\
\hline \multirow{2}{*}{ Religion } & Islam & $(\mathrm{n}=1049)$ & P-value & $711(68.0)$ & \multirow{2}{*}{0.240} \\
\hline & Non-Islamic & $150(34.0)$ & $185(30.6)$ & $335(32.0)$ & \\
\hline \multirow{2}{*}{ Victim } & Yes & $76(17.5)$ & $89(14.6)$ & $165(15.9)$ & \multirow{2}{*}{0.252} \\
\hline & No & $359(82.5)$ & $511(85.2)$ & $870(84.1)$ & \\
\hline \multirow{2}{*}{ Cyber victim } & Yes & $77(17.7)$ & $79(13.2)$ & $156(15.1)$ & \multirow{2}{*}{0.044} \\
\hline & No & $358(82.3)$ & $521(86.8)$ & $429(84.9)$ & \\
\hline
\end{tabular}




\subsection{Coping strategies for traditional and cyber victimization}

Tables 2 and 3 show the choice of the different strategies for traditional and for cyber victimization. Only $2 \%$ chose the option of checking 'Other (please state)' at the end, so this response is not considered further.
For traditional bullying, the most recommended strategy was telling someone (teacher/parent), followed by avoiding the bullies. Many also suggested asking them to stop, or ignoring it. For cyberbullying, two-thirds mentioned blocking messages/identities, and nearly half mentioned changing email address or phone number, followed by ignoring it.

Table 2. Recommended coping strategies for traditional bullying

\begin{tabular}{|c|c|c|c|c|c|c|c|c|c|}
\hline $\begin{array}{l}\text { What are the best ways to stop } \\
\text { bullying? }\end{array}$ & Younger & Older & Boys & Girls & Islamic & Non-Islamic & Victim & $\begin{array}{l}\text { Non- } \\
\text { Victim }\end{array}$ & Total \\
\hline Telling someone (teacher/parent) & $\begin{array}{c}337 \\
(57.3)\end{array}$ & $\begin{array}{c}267 \\
(58.9)\end{array}$ & $\begin{array}{c}201 \\
(45.3)\end{array}$ & $\begin{array}{c}410 \\
(67.9)\end{array}$ & $\begin{array}{c}430 \\
(60.4)\end{array}$ & $\begin{array}{c}181 \\
(53.9)\end{array}$ & $\begin{array}{c}100 \\
(60.2)\end{array}$ & $\begin{array}{c}507 \\
(58.1)\end{array}$ & $\begin{array}{c}617 \\
(58.7)\end{array}$ \\
\hline $\begin{array}{l}\text { Reporting to the police or other } \\
\text { authorities }\end{array}$ & $\begin{array}{c}166 \\
(28.2)\end{array}$ & $\begin{array}{c}159 \\
(35.1)\end{array}$ & $\begin{array}{c}113 \\
(25.5)\end{array}$ & $\begin{array}{c}215 \\
(35.6)\end{array}$ & $\begin{array}{c}227 \\
(31.9)\end{array}$ & $\begin{array}{c}100 \\
(29.8)\end{array}$ & $\begin{array}{c}41 \\
(24.7)\end{array}$ & $\begin{array}{c}286 \\
(32.8)\end{array}$ & $\begin{array}{c}340 \\
(32.3)\end{array}$ \\
\hline Asking them to stop & $\begin{array}{l}251 \\
(42.7)\end{array}$ & $\begin{array}{c}199 \\
(43.9)\end{array}$ & $\begin{array}{c}198 \\
(44.6)\end{array}$ & $\begin{array}{c}258 \\
(42.7)\end{array}$ & $\begin{array}{c}313 \\
(44.0)\end{array}$ & $\begin{array}{c}142 \\
(42.3)\end{array}$ & $\begin{array}{c}71 \\
(42.8)\end{array}$ & $\begin{array}{c}381 \\
(43.7)\end{array}$ & $\begin{array}{c}464 \\
(44.1)\end{array}$ \\
\hline Ignoring it & $\begin{array}{l}246 \\
(41.8)\end{array}$ & $\begin{array}{c}211 \\
(46.6)\end{array}$ & $\begin{array}{c}149 \\
(33.6)\end{array}$ & $\begin{array}{c}309 \\
(51.2)\end{array}$ & $\begin{array}{c}284 \\
(39.9)\end{array}$ & $\begin{array}{c}174 \\
(51.8)\end{array}$ & $\begin{array}{c}80 \\
(48.2)\end{array}$ & $\begin{array}{c}374 \\
(42.9)\end{array}$ & $\begin{array}{c}454 \\
(43.2)\end{array}$ \\
\hline Fighting back & $\begin{array}{c}120 \\
(20.4)\end{array}$ & $\begin{array}{c}103 \\
(22.7)\end{array}$ & $\begin{array}{c}131 \\
(29.5)\end{array}$ & $\begin{array}{c}90 \\
(14.9)\end{array}$ & $\begin{array}{c}134 \\
(18.8)\end{array}$ & $\begin{array}{c}89 \\
(25.6)\end{array}$ & $\begin{array}{c}42 \\
(25.3)\end{array}$ & $\begin{array}{c}179 \\
(20.5)\end{array}$ & $\begin{array}{c}226 \\
(21.5)\end{array}$ \\
\hline $\begin{array}{l}\text { Keeping a record of bullying } \\
\text { incidents }\end{array}$ & $\begin{array}{c}116 \\
(19.7)\end{array}$ & $\begin{array}{c}114 \\
(25.2)\end{array}$ & $\begin{array}{c}86 \\
(19.4)\end{array}$ & $\begin{array}{c}146 \\
(24.2)\end{array}$ & $\begin{array}{c}147 \\
(20.6)\end{array}$ & $\begin{array}{c}84 \\
(25.0)\end{array}$ & $\begin{array}{c}35 \\
(21.1)\end{array}$ & $\begin{array}{c}196 \\
(22.5)\end{array}$ & $\begin{array}{c}238 \\
(22.6)\end{array}$ \\
\hline Avoiding the bullies & $\begin{array}{c}306 \\
(52.0)\end{array}$ & $\begin{array}{c}238 \\
(52.5)\end{array}$ & $\begin{array}{c}195 \\
(43.9)\end{array}$ & $\begin{array}{c}352 \\
(58.3)\end{array}$ & $\begin{array}{c}364 \\
(51.1)\end{array}$ & $\begin{array}{c}182 \\
(54.2)\end{array}$ & $\begin{array}{c}103 \\
(62.0)\end{array}$ & $\begin{array}{c}440 \\
(50.5)\end{array}$ & $\begin{array}{c}551 \\
(52.4)\end{array}$ \\
\hline Sticking up for myself & $\begin{array}{c}200 \\
(34.0)\end{array}$ & $\begin{array}{c}163 \\
(36.0)\end{array}$ & $\begin{array}{c}195 \\
(43.9)\end{array}$ & $\begin{array}{c}352 \\
(58.3)\end{array}$ & $\begin{array}{c}238 \\
(33.4)\end{array}$ & $\begin{array}{c}125 \\
(37.2)\end{array}$ & $\begin{array}{c}68 \\
(41.0)\end{array}$ & $\begin{array}{c}294 \\
(33.7)\end{array}$ & $\begin{array}{c}363 \\
(34.5)\end{array}$ \\
\hline Making new friends & $\begin{array}{c}78 \\
(13.3)\end{array}$ & $\begin{array}{c}63 \\
(13.9)\end{array}$ & $\begin{array}{c}71 \\
(16.0)\end{array}$ & $\begin{array}{c}69 \\
(11.4)\end{array}$ & $\begin{array}{c}92 \\
(12.9)\end{array}$ & $\begin{array}{c}47 \\
(14.0)\end{array}$ & $\begin{array}{c}31 \\
(18.7)\end{array}$ & $\begin{array}{c}109 \\
(12.5)\end{array}$ & $\begin{array}{c}135 \\
(12.8)\end{array}$ \\
\hline Staying away from school & $\begin{array}{c}23 \\
(3.9)\end{array}$ & $\begin{array}{c}9 \\
(2.0)\end{array}$ & $\begin{array}{c}21 \\
(4.7)\end{array}$ & $\begin{array}{c}11 \\
(1.8)\end{array}$ & $\begin{array}{c}22 \\
(3.1)\end{array}$ & $\begin{array}{c}8 \\
(2.4)\end{array}$ & $\begin{array}{c}8 \\
(4.8)\end{array}$ & $\begin{array}{c}24 \\
(2.8)\end{array}$ & $\begin{array}{c}32 \\
(3.0)\end{array}$ \\
\hline
\end{tabular}

Table 3. Recommended coping strategies for cyber bullying

\begin{tabular}{|c|c|c|c|c|c|c|c|c|c|}
\hline $\begin{array}{c}\text { What are the best ways to stop } \\
\text { cyberbullying? }\end{array}$ & Younger & Older & Boys & Girls & Islamic & Non-Islamic & Victim & $\begin{array}{l}\text { Non- } \\
\text { Victim }\end{array}$ & Total \\
\hline Telling someone(teacher/parent) & $\begin{array}{c}211 \\
(35.9)\end{array}$ & $\begin{array}{c}158 \\
(34.9)\end{array}$ & $\begin{array}{c}129 \\
(29.1)\end{array}$ & $\begin{array}{c}244 \\
(40.4)\end{array}$ & $\begin{array}{c}242 \\
(34.0)\end{array}$ & $\begin{array}{c}131 \\
(39.0)\end{array}$ & $\begin{array}{c}46 \\
(29.3)\end{array}$ & $\begin{array}{c}321 \\
(36.4)\end{array}$ & $\begin{array}{c}387 \\
(36.8)\end{array}$ \\
\hline $\begin{array}{l}\text { Reporting to the police or other } \\
\text { authorities }\end{array}$ & $\begin{array}{l}158 \\
(26.9)\end{array}$ & $\begin{array}{c}144 \\
(31.8)\end{array}$ & $\begin{array}{c}114 \\
(25.7)\end{array}$ & $\begin{array}{c}189 \\
(31.3)\end{array}$ & $\begin{array}{c}194 \\
(27.2)\end{array}$ & $\begin{array}{c}108 \\
(32.1)\end{array}$ & $\begin{array}{c}45 \\
(28.7)\end{array}$ & $\begin{array}{c}255 \\
(28.9)\end{array}$ & $\begin{array}{c}308 \\
(29.3)\end{array}$ \\
\hline Asking them to stop & $\begin{array}{c}171 \\
(29.1)\end{array}$ & $\begin{array}{c}123 \\
(27.2)\end{array}$ & $\begin{array}{c}139 \\
(3.13)\end{array}$ & $\begin{array}{c}159 \\
(26.3)\end{array}$ & $\begin{array}{c}206 \\
(28.9)\end{array}$ & $\begin{array}{c}91 \\
(27.1)\end{array}$ & $\begin{array}{c}52 \\
(33.1)\end{array}$ & $\begin{array}{c}244 \\
(27.7)\end{array}$ & $\begin{array}{c}311 \\
(29.6)\end{array}$ \\
\hline Ignoring it & $\begin{array}{c}243 \\
(41.3)\end{array}$ & $\begin{array}{c}181 \\
(40.0)\end{array}$ & $\begin{array}{c}155 \\
(34.9)\end{array}$ & $\begin{array}{c}271 \\
(44.9)\end{array}$ & $\begin{array}{c}274 \\
(38.5)\end{array}$ & $\begin{array}{c}152 \\
(45.2)\end{array}$ & $\begin{array}{c}76 \\
(48.4)\end{array}$ & $\begin{array}{c}347 \\
(39.4)\end{array}$ & $\begin{array}{c}430 \\
(40.9)\end{array}$ \\
\hline Fighting back & $\begin{array}{c}87 \\
(14.8)\end{array}$ & $\begin{array}{c}62 \\
(13.7)\end{array}$ & $\begin{array}{c}87 \\
(19.6)\end{array}$ & $\begin{array}{c}60 \\
(9.9)\end{array}$ & $\begin{array}{c}94 \\
(13.2)\end{array}$ & $\begin{array}{c}53 \\
(15.8)\end{array}$ & $\begin{array}{c}39 \\
(24.8)\end{array}$ & $\begin{array}{c}110 \\
(12.5)\end{array}$ & $\begin{array}{c}147 \\
(14.0)\end{array}$ \\
\hline $\begin{array}{l}\text { Keeping a record of offensive } \\
\text { emails or texts }\end{array}$ & $\begin{array}{c}134 \\
(22.8)\end{array}$ & $\begin{array}{c}113 \\
(24.9)\end{array}$ & $\begin{array}{c}105 \\
(23.6)\end{array}$ & $\begin{array}{c}144 \\
(233.8)\end{array}$ & $\begin{array}{c}164 \\
(23.0)\end{array}$ & $\begin{array}{c}84 \\
(25.0)\end{array}$ & $\begin{array}{c}42 \\
(26.8)\end{array}$ & $\begin{array}{c}204 \\
(23.2)\end{array}$ & $\begin{array}{c}246 \\
(23.4)\end{array}$ \\
\hline Blocking messages/ identities & $\begin{array}{c}357 \\
(60.7)\end{array}$ & $\begin{array}{c}333 \\
(73.5)\end{array}$ & $\begin{array}{c}251 \\
(56.5)\end{array}$ & $\begin{array}{c}443 \\
(73.3)\end{array}$ & $\begin{array}{c}463 \\
(65.0)\end{array}$ & $\begin{array}{c}231 \\
(68.8)\end{array}$ & $\begin{array}{c}97 \\
(61.8)\end{array}$ & $\begin{array}{c}590 \\
(67.0)\end{array}$ & $\begin{array}{c}708 \\
(67.3)\end{array}$ \\
\hline $\begin{array}{l}\text { Changing email address or phone } \\
\text { number }\end{array}$ & $\begin{array}{c}268 \\
(45.6)\end{array}$ & $\begin{array}{c}229 \\
(50.6)\end{array}$ & $\begin{array}{c}151 \\
(34.0)\end{array}$ & $\begin{array}{c}352 \\
(58.3)\end{array}$ & $\begin{array}{c}354 \\
(49.7)\end{array}$ & $\begin{array}{c}149 \\
(44.3)\end{array}$ & $\begin{array}{c}89 \\
(56.7)\end{array}$ & $\begin{array}{c}410 \\
(46.5)\end{array}$ & $\begin{array}{c}505 \\
(48.0)\end{array}$ \\
\hline
\end{tabular}




\subsection{Differences in coping strategies for traditional and cyber victimization}

Five of the strategy options for traditional and cyber victimization were identical (shown as the top five in Tables 2 and 3), and a sixth, on keeping a record, is closely corresponding. (The other strategies were more specific to the offline or online situation).

Choice of these 6 strategies options were compared for traditional and cyber domains, using chi-square $2 \times 2$ contingency tests. Three out of six comparisons were significant. Telling someone (teacher/parent) was more often recommended for traditional than cyber victimization, $\left.\chi_{(1}^{2}\right)=108.0, \mathrm{p}<.001$; this was also true of asking them to stop, $\left.\chi_{(1}^{2}\right)=52.3, \mathrm{p}<.001$; and fighting back, $\left.\chi_{(1)}^{2}\right)=17.9, \mathrm{p}<.001$. However there was no significant difference for reporting to the police or other authorities, $\left.\chi_{(1}^{2}\right)=1.3, \mathrm{p}=.254$; ignoring it, $\left.\chi_{(1}^{2}\right)=2.0, \mathrm{p}=.158$; or keeping a record (of bullying incidents/of offensive emails or texts), $\left.\chi_{(1}^{2}\right)=0.8, \mathrm{p}=.377$.

\subsection{Factors affecting coping strategies}

We examined the influence of four binary-coded factors (age, gender, religion, and victim/non-victim status) using multiple linear regression. The numbers and percentages by each factor are shown in Tables 2 and 3; totals vary slightly by factor, due to a few missing demographic values.

For the victim/non-victim comparisons, we used traditional victim/non-victim status for traditional coping strategies (Table 2 ); and cyber victim/non-victim status for cyber coping strategies (Table 3). Altogether (over 18 strategies in Tables 2 and 3) we found 4 significant age differences, 15 significant gender differences, 2 significant religion differences, and 4 significant victim/ non-victim status differences.

\subsection{Age differences in coping strategies}

For traditional coping strategies, there were two significant age differences. Older pupils, more than younger pupils, recommended reporting to the police or other authorities $(t=2.35, \mathrm{p}=.019)$, and keeping a record of bullying incidents $(\mathrm{t}=2.28, \mathrm{p}=.023)$.

For cyber coping strategies, there were two significant age differences. Older pupils, more than younger pupils, recommended reporting to the police or other authorities $(\mathrm{t}=2.00, \mathrm{p}=.046)$, and blocking messages/identities ( $\mathrm{t}=4.41, \mathrm{p}<.001)$.

\subsection{Gender differences in coping strategies}

For traditional coping strategies, there were eight significant age differences. Five favored girls: they were more likely to recommend Telling someone (teacher/parent) $(\mathrm{t}=7.08, \mathrm{p}<.001)$, Reporting to the police or other authorities $(t=2.35, p=.019)$, Ignoring it $(\mathrm{t}=3.14, \mathrm{p}=.002)$, Avoiding the bullies $(\mathrm{t}=4.70, \mathrm{p}<.001)$, and Sticking up for myself without fighting $(\mathrm{t}=2.24, \mathrm{p}=.025)$. Three favored boys: they were more likely to recommend Fighting back $(\mathrm{t}=5.58, \mathrm{p}<.001)$, Making new friends $(\mathrm{t}=2.03, \mathrm{p}=.043)$, or Staying away from school $(\mathrm{t}=2.38, \mathrm{p}=.018)$.

For cyber coping strategies, there were seven significant age differences. Five favored girls: they were more likely to recommend Telling someone (teacher/parent) $(\mathrm{t}=3.64, \mathrm{p}<.001)$, Reporting to the police or other authorities $(\mathrm{t}=1.98, \mathrm{p}=.048)$, Ignoring it $(\mathrm{t}=3.54, \mathrm{p}<.001)$, Blocking messages/identities $(\mathrm{t}=5.77, \mathrm{p}<.001)$, and Changing email address or phone number $(\mathrm{t}=7.95, \mathrm{p} .001)$. Two favored boys: they were more likely to recommend Asking them to stop $(\mathrm{t}=1.98, \mathrm{p}=.048)$, or Fighting back $(\mathrm{t}=4.14, \mathrm{p}<.001)$.

\subsection{Religion differences in coping strategies}

For traditional coping strategies, there were two significant religion differences. Non-Islamic, more than Islamic, pupils, recommended Ignoring it $(\mathrm{t}=4.01, \mathrm{p}<.001)$, and Fighting back $(\mathrm{t}=2.50, \mathrm{p}=.013)$.

For cyber coping strategies, there were no significant differences by religion.

\subsection{Victim/non-victim status differences in coping strategies}

For traditional coping strategies, there was one significant victim/ non-victim difference. Traditional victims, more than non-victims, recommended avoiding the bullies $(\mathrm{t}=2.97, \mathrm{p}=.003)$.

For cyber coping strategies, there were three significant victim/ non-victim differences. Cyber victims, more than non-victims, recommended ignoring it $(\mathrm{t}=2.10, \mathrm{p}=.036)$, fighting back $(\mathrm{t}=3.90$, $\mathrm{p}<.001)$, and changing email address or phone number $(\mathrm{t}=2.83$, $\mathrm{p}=.005)$

\section{DISCUSSION}

The data on experiences of traditional and cyber bullying showed that these were not uncommon, with significant minorities being involved, around $15 \%$ for both traditional bullying and cyberbullying. This study provides new data on what coping strategies were seen as best for traditional and cyberbullying, among adolescents in the southern provinces of Thailand; and factors affecting the choice of strategies. The range of strategy options in the questionnaire appeared satisfactory, in that all (apart from Staying away from school) were chosen by over $10 \%$ of respondents, and the option to fill in additional strategies was only taken by around $2 \%$.

For traditional bullying, the most common recommended strategy was to Tell someone (teacher or parent). This was significantly less common for cyberbullying. A lesser willingness to tell adults about cyber victimization than traditional victimization has been reported in other studies (Slonje \& Smith, 2008). At least in this historical period as ICT changes so fast, adolescents seem to have less confidence in an adult's ability to understand and act constructively in the cyber domain. Nevertheless the relatively high figure for telling are encouraging, as seeking help by telling someone has often been found to be an effective response in western studies, for cyberbullying as for traditional bullying (Machmutow et al., 2012; Smith et al., 2004). The effectiveness does depend on the adult told, responding in an effective and consistent manner. In this respect more parent education, and clear school policies on bullying, are important steps to take in Thailand (Amaraphibal, 2016).

Other common strategies recommended for traditional bullying were Avoiding the bully, Asking them to stop, and Ignoring it. These might all be reasonable strategies, depending on the circumstances. Asking them to stop, and also Fighting back, were less recommended for cyberbullying. Uncertainty of who the perpetrator is, or the diffusion of perpetration in cyberbullying through passing on or repeated viewings of hurtful material (Slonje, Smith \& Frisén, 2012) could make Asking them to stop a more awkward strategy, while Fighting back, at least in the physical sense, is also less feasible in the cyber domain.For cyberbullying however the most common suggested responses were Blocking messages/identities of bullies, or Changing email addresses or phone numbers. These can be effective in the short 
term, but are unlikely to be effective in the longer term or in changing behavior of cyberbullies. From the point of view of action by the school, Ang (2015) discusses both general empathy training and modifying beliefs supportive of aggression, and more specific guidelines for internet behavior, as useful approaches.

Age changes in the recommended strategies were, on the whole, modest. This may reflect that all the pupils were already at secondary school and in adolescence; previous studies reporting large age changes have generally also included pre-adolescent children. Nevertheless older adolescents in this study were more ready to Report to the police or other authorities, for both traditional and cyberbullying. This might reflect both greater confidence in approaching more distant adults (other than parents and teachers), and also more awareness of the legal implications. Older adolescents were also more likely to recommend Keeping a record of bullying incidents (traditional) and Blocking messages/ identities (cyber), both perhaps aspects of competence increasing with age.

In contrast to age, there were large gender differences, found in almost all strategies. Girls were more likely to Tell someone (teacher/parent) and Report to the police or other authority, for both traditional and cyber victimization. Greater willingness to tell someone about bullying has been one of the most consistent findings regarding coping strategies in western studies (Naylor et al., 2001), and this is clearly true of this Thai sample as well. Similarly boys' greater inclination to Fight back has been reported in western studies (Smith et al., 2001) and is replicated here in Thailand.

Other gender differences suggest some new avenues of investigation. For cyber victimization, girls in this sample were more likely than boys to recommend both Blocking messages/identities, and Changing email address or phone number; these were both popular strategies but substantially more so for girls. Perhaps girls (more likely to be smart phone owners in this sample) felt more competent about doing such actions; and/or perhaps they might be more effective for the kinds of relational bullying more common in girls (Besag, 2006). Similarly girls were more likely to recommend Ignoring it (both traditional and cyber) and this might be more effective for relational bullying than for the physical bullying more common in boys.

One strategy boys recommended more for traditional bullying was Making new friends. Although this difference was relatively small, it does (unlike Fighting back) represent a probably more constructive strategy. Staying with friends can be a protective factor, most obviously for face-to-face bullying (Fox \& Boulton, 2006). For pupils who might find it difficult to make new friends in this way, peer support schemes (including befriending schemes), used with some success in western countries (Cowie \& Smith, 2010), and might also be useful in Thai schools.

So far as we are aware, religion has not been considered previously in relation to coping strategies. This particular sample included both Islamic and (almost entirely) Buddhist samples. At the time of the study, Islamic and Buddhist pupils were educated in separate schools. We had no expectations of differences, as both Islam and Buddhism preach non-violence, but a previous study in the same southern provinces (Laeheem et al., 2009) had found non-Muslim pupils more involved in traditional bullying perpetration, than Muslim pupils. In fact, there were very few differences by religion, and none for cyber victimization; but for traditional victimization, Non-Muslim pupils were more likely to recommend Ignoring it, and Fighting back. Although significant, the differences are relatively small, and unless replicated it may be premature to hypothesize reasons for these findings.
Finally, some differences were found between strategies recommended by victims, and non-victims. Here, it might be supposed that victims might think of less successful strategies, such as internalizing ones (Bijttebier \& Vertommen, 1998). We found that indeed victims did favor Avoiding the bully for traditional bullying, and Ignoring it, Changing email address or phone number, and especially Fighting back, for cyberbullying. There is some evidence that these mainly rather passive strategies are less successful (Machmutow et al., 2012), and while fighting back is not passive, it is unlikely to be successful given the power imbalance normally found in cases of bullying. These findings do suggest the importance of social skills training and assertiveness training for likely victims of bullying, so that they can adopt more active strategies (such as telling someone, keeping a record of bullying incidents, making new friends) (Fox \& Boulton, 2006; Scheitauer et al., 2012). This should of course not detract from the responsibilities of others (school, teachers, and peer group) in preventing bullying.

Some limitations of this study should be noted. First, all the data is self-report. Self-report data is very commonly used in studies of bullying, and has the advantage that pupils know best about their own experience. However there is some danger of self-serving bias, for example being reluctant to admit to bullying, or to aspects of victimization (such as possibly being called gay, in this study). Peer nominations can be an excellent method for looking at correlates of bully or victim role, although not so feasible for larger-scale studies.

Secondly, the students were asked about which strategies they thought best to use. This may be different from strategies they would actually use, which was not asked about. Nevertheless, their opinions about strategies has its own intrinsic interest as an indicator of how they think about coping with victimization, should it happen - a question which all students can answer, irrespective of their recent victim status.

Third, the option of neither telling someone put teachers and parents together, but did nor specifically mention friends. In future these different possibilities should be separated. Especially for cyber victimization, pupils may be more willing to tell friends but less willing to tell teachers (Slonje \& Smith, 2010; Zhou et al., 2013).

\section{CONCLUSIONS}

This study showed that the numbers of adolescents bullied (traditionally or cyber) in southern Thailand is sufficient to be of concern. It has provided new data on the range of coping strategies pupils think best to use, with a direct comparison of many strategies between traditional and cyberbullying. While some findings are similar to those in western countries, others are distinct. Some gender differences may provide important leads for tailoring internet safety programs (for example, safe practices in social networking use; and importance of peer support in coping with being bullied). The findings on religion are new as well, although would need to be replicated given the small effect sizes here.

Bullying can have very serious consequences, even suicide, as has appeared in many news reports in Thailand as well as other countries (Amaraphibal, 2016). Just as in other countries, Thai adolescents use a range of possible coping strategies, some more optimal than others. An encouraging finding of this study was the large proportion of pupils who recommended telling someone if bullied, and this needs to be built upon by teachers and parents. Besides helping bullied students develop good coping strategies, 
schools, teachers, parents and peers have important roles to play in reducing the prevalence and harmful consequences of bullying.

In western countries, there are now many resources and intervention programs to help schools, families and young people cope with the problems of bullying (Smith, 2014), and increasingly these are being developed for cyberbullying (Campbell \& Bauman, in press). At present resources, and intervention work, is very limited in Thailand. This and further research can assist in the development of such resources and programs, designed for Thai pupils, families and schools.

\section{FUNDING}

This research article is supported by Humanities Grant of Prince of Songkla University.

\section{REFERENCES}

Amaraphibal, A. (2016). Cyber-bullying victimization among youths: Risk factor, mental health impacts and reporting to the third person. Research Methodology \& Cognitive Science, 14, 60-73. Retrieved from https://www.tci-thaijo.org/index.php/RMCS/article/view/59642/48998

Ang, R. P. (2015). Adolescent cyberbullying: A review of characteristics, prevention and intervention strategies. Aggression and Violent Behavior, 25, 35-42. doi:10.1016/j.avb.2015.07.011

Aricak, T., Siyahhan, S., Uzunhasanoglu, A., Saribeyoglu, S., Ciplak, S., \& Yilmaz, N. (2008). Cyberbullying among Turkish adolescents. Cyberpsychology \& Behavior, 11(3), 253-261. doi:10.1089/cpb.2007.0016

Besag, V. E. (2006). Understanding girls'friendships, fights and feuds. Maidenhead: Open University Press.

Bijttebier, P., \& Vertommen, H. (1998). Coping with peer arguments in school-age children with bully/victim problems. British Journal of Educational Psychology, 68, 387-394. doi:10.1111/j.2044-8279.1998.tb01299.x

Campbell, M., \& Bauman, S. (Eds.) (in press). Reducing cyberbullying in schools. Elsevier.

Cowie, H., \& Smith, P. K. (2010). Peer support as a means of improving school safety and reducing bullying and violence. In B. Doll, W. Pfohl, \& J. Yoon (Eds.), Handbook of Youth Prevention Science (pp. 177-193). New York: Routledge.

Fox, C. L., \& Boulton, M. J. (2006). Friendship as a moderator of the relationship between social skills problems and peer victimisation. Aggressive Behavior, 32, 110-121. doi:10.1002/ab.20114

Hunter, S. C., \& Boyle, J. M. E. (2004). Appraisal and coping strategy use of victims of school bullying. British Journal of Educational Psychology, 74, 83-107. htdoi:10.1348/000709904322848833

Juvonen, J., \& Gross, E. F. (2008). Extending the school grounds? Bullying experiences in cyberspace. Journal of School Health, 78, 496-505._doi:10.1111/j.17461561.2008.00335.x

Kanetsuna, T., \& Smith, P. K. (2002). Pupil insights into bullying, and coping with bullying: A bi-national study in Japan and England. Journal of School Violence, 1, 5-29. doi:10.1300/J202v01n03_02

Kowalski, R. M., Giumetti, G. W., Schroeder, A. N., \& Lattanner, M. R. (2014). Bullying in the digital age: A critical review and meta-analysis of cyberbullying research among youth. Psychological Bulletin, 140, 1073-1137. doi:10.1037/ a0035618

Kristensen, S. M., \& Smith, P. K. (2003). The use of coping strategies by Danish children classed as bullies, victims, bully/victims, and not involved, in response to different (hypothetical) types of bullying. Scandinavian Journal of Psychology, 44, 479-488. doi:10.1046/j.1467-9450.2003.00369.x

Laeheem, K., Kuning, M., \& McNeil, N. (2009). Bullying: Risk factors becoming 'bullies'. Asian Social Science, 5, 50-57. doi:10.5539/ass.v5n5p50

Machmutow, K., Perren, S., Sticca, F., \& Alsaker, F. D. (2012). Peer victimization and depressive symptoms: Can specific coping strategies buffer the negative impact of cybervictimization? Emotional and Behavioral Difficulties, 17, 403-420. doi:10.1080/13632752.2012.704310

Naylor, P., Cowie, H., \& del Rey, R. (2001). Coping strategies of secondary school children in response to being bullied. Child Psychology and Psychiatry Review, 6, 114-120. doi:10.1017/S1360641701002647

Olweus, D. (1999). Sweden. In P. K. Smith, Y. Morita, J. Junger-Tas, D. Olweus, R. Catalano, \& P. Slee (Eds.), The nature of school bullying: A cross-national perspective (pp. 7-27). London: Routledge.

Patchin, J. W., \& Hinduja, S. (2012). Bullies move beyond the schoolyard: A preliminary look at cyberbullying. Youth Violence and Juvenile Justice, 4(2), 148-169.Promnork, C. (2015). Cyberbullying behavior in $4^{\text {th }}-6^{\text {th }}$ grade students of a Bangkok Municipal school; a qualitative study. Faculty of Graduate Studies, Bangkok: Mahidol University._doi:10.1177/1541204006286288
Raskauskas, J., \& Huynh, A. (2015). The process of coping with cyberbullying: A systematic review. Aggression and Violent Behavior, 23, 118-125. doi:10.1016/j. avb.2015.05.019

Riebel, J., Jäger, R. S., \& Fischer, U. C. (2009). Cyberbullying in Germany - an exploration of prevalence, overlapping with real life bullying and coping strategies. Psychology Science Quarterly, 51, 298-314. Retrieved from http://citeseerx.ist.psu.edu/viewdoc/download?doi=10.1.1.599.3516\&rep=rep1\&type=pdf

Rigby, K. (2002). New perspectives on bullying. London: Jessica Kingsley.

Scheitauer, H., Hess, M., Schultze-Krumbholz, A., \& Bull, H. D. (2012). Schoolbased prevention of bullying and relational aggression in adolescence: The fairplayer.manual. In D. Strohmeier \& G. G. Noam (Eds.), Evidence-based bullying prevention programs for children and youth. New Directions for Youth Development, 133, 55-70. doi:10.1002/yd.20007

Sittichai, R. (2014). Information technology behavior cyberbullying in Thailand: incidence and predictors of victimization and cyber-victimization. Asian Social Science, 10, 132-139.

Sittichai, R., \& Smith, P. K. (2015). Bullying in South-East Asian countries: A review. Aggression and Violent Behavior, 23, 22-35. doi:10.5539/ass.v10n11p132

Sittichai, R., \& Tudkea, T. (2015). Cyberbullying behavior for youth in the three Southern Border Provinces of Thailand (Research report). Pattani: Faculty of Humanities and Social Sciences Prince of Songkla University. doi:10.5539/ass. v10n11p132

Slonje, R., \& Smith, P. K. (2008). Cyberbullying: another main type of bullying? Scandinavian Journal of Psychology, 49, 147-154. doi:10.1111/j.14679450.2007.00611.x

Slonje, R., Smith, P. K., \& Frisén, A. (2012). Processes of cyberbullying, and feelings of remorse by bullies: A pilot study. European Journal of Developmental Psychology, 9, 244-259. doi:10.1080/17405629.2011.643670

Smith, P. K. (2014). Understanding school bullying: Its nature and prevention strategies. London: Sage. doi:10.4135/9781473906853

Smith, P. K., Mahdavi, J., Carvalho, M., Fisher, S., Russell, S., \& Tippett, N. (2008). Cyberbullying: its nature and impact in secondary school pupils. Journal of Child Psychology and Psychiatry, 49, 376-385. doi:10.1111/j.14697610.2007.01846.x

Smith, P. K., Shu, S., \& Madsen, K. (2001). Characteristics of victims of school bullying: Developmental changes in coping strategies and skills. In J. Juvonen \& S. Graham (Eds.), Peer harassment at school: The plight of the vulnerable and victimised (pp. 332-352). New York: Guildford.

Smith, P. K., Talamelli, L., Cowie, H., Naylor, P., \& Chauhan, P. (2004). Profiles of non-victims, escaped victims, continuing victims and new victims of school bullying. British Journal of Educational Psychology, 74, 565-581. doi:10.1348/0007099042376427

Tokunaga, R. S. (2010). Following you home from school: A critical review and synthesis of research on cyberbullying victimization. Computers in Human Behavior, 26, 277-287. doi:10.1016/j.chb.2009.11.014

Vandoninck, S., \& d'Haenens, L. (2015). Children's online coping strategies: Rethinking coping typologies in a risk-specific approach. Journal of Adolescence, 45, 225-236. doi:10.1016/j.adolescence.2015.10.007

Vollink, T., Bolman, C. W., Dehue, F., \& Jacobs, N. C. L. (2013). Coping with cyberbullying: Differences between victims, bully-victims, and children not involved in bullying. Journal of Community and Applied Social Psychology, 23, 7-24. doi: 10.1002 /casp. 2142

Zhou, Z., Tang, H., Tian, Y., Wei, H., Zhang, F., \& Morrison, C. M. (2013). Cyberbullying and its risk factors among Chinese high school students. School Psychology International, 34, 630-647. doi:10.1177/0143034313479692

How to cite this article: Sittichai, R., \& Smith, P. K. (2018). Bullying and Cyberbullying in Thailand: Coping Strategies and Relation to Age, Gender, Religion and Victim Status. Journal of New Approaches in Educational Research, 7(1), 24-30. doi: 10.7821/naer.2018.1.254 